\title{
Pola Pemanfaatan Ruang Pada Selamatan Desa di Permukiman Perkotaan \\ Studi Kasus: Selamatan Desa RW IV Kelurahan Jajar Tunggal Surabaya
}

\author{
Dahlia Astari, Agung Murti Nugroho \\ Program Magister Arsitektur Lingkungan Binaan, Fakultas Teknik, Universitas Brawijaya \\ dahlia_astari@yahoo.co.id
}

\begin{abstract}
ABSTRAK
Selamatan desa adalah ritual yang bertujuan untuk mengucapkan rasa syukur atas panen yang melimpah dan menghindarkan diri dari mara bahaya. Di beberapa daerah di Kota Surabaya masih melaksanakan tradisi tersebut terutama di daerah pertanian. Meskipun demikian, RW IV Kelurahan Jajar Tunggal masih mempertahankan tradisi tersebut meskipun kondisi permukiman berada di wilayah padat perkotaan dengan penduduk yang mayoritas beragama Islam dan bekerja di sektor swasta dan bekerja sebagai tukang. Oleh karena itu, penelitian ini ingin mengetahui pola pemanfaatan ruang yang terjadi pada pelaksanaan selamatan desa dengan memanfaatkan jalan utama untuk melaksanakan tradisi tersebut. Metode yang digunakan adalah deskriptif kualitatif dengan pendekatan behavior mapping dengan pemetaan perilaku yaitu place centered maps. Hasil dari penelitian ini adalah bahwa pola pemanfaatan ruang di jalan utama kampung berbentuk menyebar dan mengelompok di daerah yang rindang dan dekat dengan warung/toko. Sedangkan pada saat selamatan desa, pusat aktivitas terjadi hampir di sepanjang jalan utama kampung.
\end{abstract}

Kata kunci: selamatan desa, pemanfaatan ruang, jalan utama

\begin{abstract}
Selamatan desa is a ritual that aims to create a sense of gratitude for a bountiful harvest and refrain from danger. In some areas in the city of Surabaya still performs this tradition, especially in the areas that still have agricultural land. However, RW IV Kelurahan Jajar Tunggal still performs this tradition even though the conditions in the settlements located in the dense urban area with a Muslim majority society and livelihood as private sector employees and craftmans. Therefore, this study wants to know the pattern of utilization of space that occurs in Selamatan desa that using the main street for the tradition. The Method used is descriptive qualitative with environment behavior study approach with behavior mapping by place centered maps. The results of this study indicate that the pattern of use of the street in everyday activities shaped with spread and clustered form in an area close to stall or shady areas. While at Selamatan desa, the concentration of activity spread all along the main street
\end{abstract}

Keywords: Selamatan desa, utilization of space, main street

\section{Pendahuluan}

Selamatan desa diidentikkan dengan tradisi ruwahan karena dilaksanakan pada bulan ruwah pada penanggalan agama Islam. Selamatan desa identik dengan masyarakat pertanian atau penduduk nelayan yang disebut dengan tradisi sedekah laut dan memiliki ruang terbuka untuk pelaksanaan acaranya. Akan tetapi pada kenyataannya, pelaksanaan tradisi ini tidak hanya dilaksanakan di daerah pertanian atau kampung nelayan saja. Kota Surabaya sebagai kota metropolitan Langkau Betang: Vol. 2, No.1 (ISSN 2355-2484) juga memiliki beberapa daerah yang masih melaksanakan tradisi tersebut. Salah satunya adalah yang dilaksanakan oleh RW IV Kelurahan Jajar Tunggal.

Kampung ini berada di wilayah yang padat di tengah perkotaan dengan penduduk yang mayoritas bekerja di sektor swasta dan tukang kayu. Tradisi selamatan desa pada tahun ini dilaksanakan pada tanggal 30 Mei hingga 01 Juni 2014. Agenda utama dalam tradisi selamatan desa adalah malam kesenian dengan pertunjukan ludruk dan pengajian

Hal. 42 
umum. Kondisi kampung yang berada pada wilayah padat perkotaan membuat pelaksanaan acara dilaksanakan di jalan utama kampung yaitu Jalan Kramat II. Pelaksanaan selamatan desa memanfaatkan ruang yang ada di jalan ini untuk mendukung kelancaran pelaksanaan selamatan desa. Pola pemanfaatan ruang dalam pelaksanaan selamatan desa ini menjadi rumusan masalah dalam penelitian ini. Manfaat dari penelitian ini diharapkan dapat memberikan kontribusi dalam pengembangan kajian Arsitektur Lingkungan Binaan terutama pada kajian pelaksanaan tradisi yang dilaksanakan di wilayah perkotaan.

\section{Kajian Literatur}

Menurut Lang (2004), lingkungan akan mempengaruhi terbentuknya perilaku melalui empat cara, yaitu antara lain:

1. Lingkungan membatasi perilaku yang dilakukan oleh manusia. Pembatasan perilaku tersebut dikarenakan adanya batas fisik dan batas simbolik.

2. Lingkungan menentukan bagaimana manusia bertingkah laku. Manusia akan menyesuaikan perilakunya sesuai dengan lingkungan tempatnya berada.

3. Lingkungan membentuk kepribadian. Lingkungan akan membentuk pola perilaku dari suatu individu yang akan menjadi bagian dari dirinya dan akan menentukan kehidupan individu tersebut di masa yang akan datang.

4. Lingkungan akan membentuk citra diri manusia yang berada dalam lingkungan tersebut.

Menurut Roger Barker dalam Zeisel (1981), behavior setting merupakan keterkaitan antara lingkungan dan perilaku yang saling menentukan dan tidak dapat dipisahkan satu sama lain. Menurut Barker, behavior setting merupakan tingkah laku manusia dalam hubungan timbal baliknya dengan lingkungan. Behavior setting dapat diartikan sebagai suatu interaksi antara suatu kegiatan dengan tempat yang mewadahinya (Zeisel,1981).

Menurut Laurens (2004), behavior setting merupakan perpaduan antara kegiatan manusia dan ruang yang mewadahinya, yang memiliki empat kriteria sebagai berikut:
1. Terdapat kegiatan yang dilaksanakan secara berulang-ulang yang membentuk suatu pola perilaku dari masyarakat.

2. Lingkungan masyarakat yang digunakan berkaitan erat dengan pola perilaku yang telah terbentuk.

3. Pola perilaku dan lingkungan yang mewadahi kegiatan membentuk hubungan yang sama.

4. Hubungan antara pola perilaku dan lingkungan tersebut terjadi pada suatu periode tertentu.

Permukiman secara fisik tidak sekedar sebagai tempat tinggal saja tetapi merupakan hubungan yang terbentuk dari kegiatan manusia melalui pola - pola yang mengatur dan menjaga keseimbangan alam. Kehidupan manusia yang berkembang akan senantiasa melakukan penyesuaian-penyesuaian terhadap lingkungan permukimannya. Pada proses penyesuaian itulah akan muncul permasalahan pemanfaatan ruang permukimannya berkaitan dengan perubahan pola perilaku masyarakat atau fisik sarana yang dibutuhkan, baik secara pribadi maupun bersama- sama. Pola pemanfaatan ruang sangat ditentukan oleh perilaku manusia yang memanfaatkan ruang tersebut dan merupakan bagian dari fungsi sistem yang lebih besar dari ruang yang melingkupi tersebut (Wahid dan Alamsyah, 2013).

Rapoport (1977) mengemukaan lima elemen dasar pola penggunaan ruang yang terdiri dari:

1. Ruang kegiatan manusia (home range) Ruang kegiatan manusia (home range) merupakan ruang yang digunakan oleh penduduk dalam melakukan pergerakan atau aktivitas yang dapat terdiri dari beberapa lokasi dan jaringan penghubung antar lokasi tersebut. Wujud dari home range tersebut dipengaruhi oleh karakteristik masyarakatnya.

2. Area inti (core area)

Area inti (core area) merupakan wilayah yang paling sering dipakai oleh masyarakat dalam melaksanakan aktivitasnya dan dikontrol oleh masyarakat itu sendiri. Core area (area inti) dimanfaatkan oleh masyarakat yang memiliki sistem sosial dan memiliki hubungan personal yang dekat.

Hal. 43 
3. Teritori (territory)

Teritori (territory) merupakan ruang yang dimiliki oleh sekelompok masyarakat yang memiliki kepentingan yang sama terhadap ruang tersebut. Ruang tersebut disadari atau tidak, dikontrol dan dipertahankan oleh masyarakatnya.

4. Area terkontrol (jurisdiction)

Area terkontrol (jurisdiction) merupakan ruang yang dikuasai dan dikontrol oleh masyarakat penggunanya untuk sementara waktu dan tidak bersifat permanen.

5. Ruang personal (personal distance/space)

Ruang personal (personal distance/space) merupakan area yang dikuasai dan dikontrol oleh masing masing individu.

Masyarakat dengan karakteristik berupa pandangan hidup, kepercayaan, nilai dan norma yang dianut akan menentukan perilaku yang tercermin dalam pola hidup dalam masyarakat. Pola hidup masyarakat tersebut akan dilaksanakan melalui wadah - wadah yang saling berhubungan dan mendukung yaitu pemanfaatan ruang dalam melaksanakan entitas budaya dalam masyarakat. Perwujudan pola dan struktur ruang dalam ruang permukiman tradisional memisahkan ruang - ruang suci / sakral dengan ruang dengan fungsi kegiatan manusia. Fleksibilitas ruang, dan waktu dalam sistem keruangan masyarakat menyebabkan terjadinya adaptasi nilai - nilai keruangan yang disesuaikan dengan kebutuhan masyarakatnya.

Penelitian ini membahas mengenai pelaksanaan tradisi selamatan desa yang dilaksanakan di kawasan padat perkotaan dan berkaitan erat dengan lingkungan dan perilaku masyarakat. Menurut Haryadi \& Setiawan (1995), teknik survey yang tepat dipakai dalam penelitian mengenai perilaku dan lingkungan adalah teknik behavioral mapping dengan pemetaan perilaku place centered maps. Teknik place-centered maps lebih memfokuskan diri pada suatu tempat yang spesifik tanpa melihat ukuran tempat tersebut besar ataukah kecil. Teknik ini digunakan untuk mengetahui upaya individu maupun masyarakat dalam memanfaatkan dan mengakomodasikan perilakunya dalam suatu tempat dan waktu tertentu. Beberapa tahapan yang dilakukan dalam teknik ini antara lain:

1. Membuat perkiraan mengenai elemen - elemen fisik apa sajakah yang mempengaruhi perilaku invividu maupun masyarakat pengguna ruang yang kemudian membuat sketsa dari tempat atau setting tersebut. Dalam tahapan ini, peneliti harus mengetahui tentang wilayah yang menjadi objek amatannya.

2. Melakukan pengamatan terhadap perilaku individu ataupun masyarakat yang terjadi dan melakukan pencatatan terhadap perilaku tersebut sekaligus menentukan simbol atau tanda - tanda tertentu pada sketsa setting yang telah dibuat sebelumnya.

Melalui place centered maps, maka penelitian ini akan fokus pada ruang ruang yang digunakan dalam kegiatan sehari-hari dan saat acara selamatan desa. Penelitian ini akan mengamati dan menelaah upaya individu maupun masyarakat dalam memanfaatkan ruang ruang publik tersebut dalam melaksanakan aktivitas sehari-hari dan saat tradisi selamatan desa sehingga menghasilkan pola pemanfaatan ruang pada saat aktivitas sehari-hari dan saat aktivitas selamatan desa.

\section{Metode Penelitian}

Peneliti menggunakan metode deskriptif kualitatif. Teknik survey yang digunakan adalah teknik behavioral mapping dengan pemetaan perilaku, yaitu place centered maps. Tahapan yang dilakukan adalah mengidentifikasi ruang ruang yang digunakan oleh kelompok masyarakat dalam melaksanakan tradisi selamatan desa yang diwujudkan dalam sketsa setting ruang. Langkah kedua adalah melakukan pengamatan dan pencatatan terhadap aktivitas kelompok masyarakat dalam tradisi selamatan desa dan memberi tanda pada sketsa yang telah dibuat sebelumnya.

Penelitian ini dilakukan dengan beberapa cara yaitu observasi, wawancara dan studi literatur. Teknik penentuan sampel yang digunakan dalam penelitian ini adalah teknik Snowball Sampling (Teknik Bola Salju). Key person yang ditetapkan adalah Pak Misnan sebagai Ketua penyelenggara selamatan 
desa dan beliau merekomendasikan para perangkat kampung yang terlibat dan rumahnya juga berada pada area inti pelaksanaan selamatan desa tersebut.

Observasi dilaksanakan berdasarkan hari kerja atau hari biasa selama tujuh hari dari Senin hingga hari Minggu serta saat pelaksanaan selamatan desa yang dilaksanakan selama tiga hari dari tanggal 30 Mei 2014 hingga 01 Juni 2014. Pelaksanaan observasi dilaksanakan dengan interval waktu 2 jam dari pukul 06.00 WIB hingga 22.00 WIB. Jalan

Kramat II sebagai wilayah penelitian dibagi menjadi 14 spot yang didasarkan pada pengelompokan aktivitas yang dilakukan saat pelaksanaan selamatan desa. Pembagian spot tersebut dapat terlihat dalam gambar berikut ini.

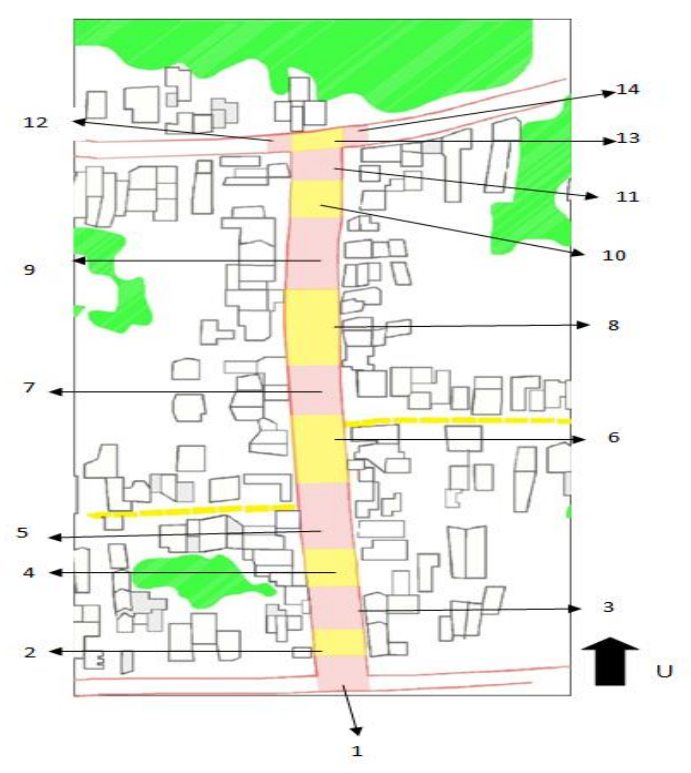

Gambar 1: Pembagian spot pada Jalan Kramat II. Sumber: Peta Persil-Dokumen Penelitian, 2014
1. Spot 1: merupakan gerbang kampung

2. Spot 2: berada di depan pos RW

3. Spot 3: area di depan rumah penjual air bersih

4. Spot 4:area di depan warung gado-gado

5. Spot 5: warung kopi dan penjual buah

6. Spot 6: persimpangan dengan Jalan Dukuh Kramat II

7. Spot 7: kios makanan kecil

8. Spot 8: bengkel las

9. Spot 9: rumah pembuatan meubel

10. Spot 10: kios jajanan

11. Spot 11: dekat dengan persimpangan Jalan Dukuh Kramat I dan adanya penjual buah

12. Spot 12: berada pada pertemuan dengan Jalan Dukuh Kramat I

13. Spot 13: berada di ujung Jalan Kramat II

14. Spot 14: warung makanan yang dekat dengan warung makanan.

\section{Hasil dan Pembahasan}

Jalan Kramat II merupakan wilayah pelaksanaan selamatan desa. Jalan Kramat II berada pada RW IV Kelurahan Jajar Tunggal, Kecamatan Wiyung Kota Surabaya. Penggunaan lahan di jalan ini mayoritas digunakan untuk tempat tinggal dan hanya sebagian kecil digunakan untuk tempat usaha. Lebar jalan sekitar 4 meter dan panjang jalan mencapai $300 \mathrm{~m}$.

RW IV kelurahan Jajar Tunggal merupakan wilayah padat di tengah perkotaan. Hal tersebut mengakibatkan wilayah ini menjadi wilayah padat penduduk dan hampir tidak memiliki ruang terbuka hijau. Mayoritas tata guna lahan pada jalan Kramat II merupakan tempat tinggal dengan halaman yang cukup sempit. Sedangkan fasilitas umum seperti musholla dan makam berada pada Jalan Dukuh Kramat.

Beberapa warga memiliki usaha yang dibangun di tempat tinggal mereka terutama di bagian teras rumah masingmasing dan hanya sedikit warga yang mempunyai lahan sendiri untuk membangun usaha di tempat lain karena keterbatasan lahan dan dana yang dimiliki. Selain itu, beberapa rumah merupakan satu kompleks rumah kos dan kontrakan. 


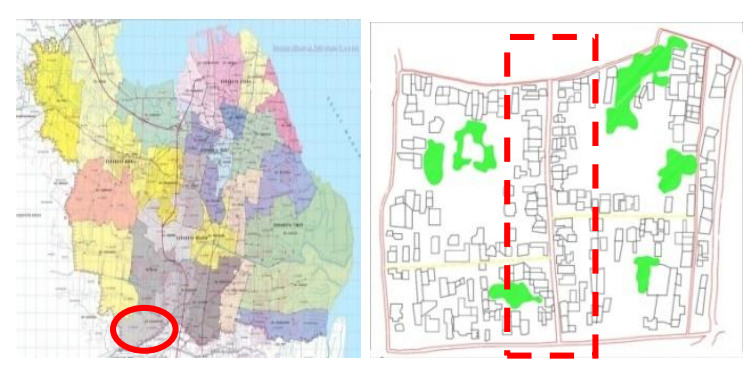

Gambar 2: Wilayah pelaksanaan selamatan desa. Sumber: Data Kecamatan Wiyung, 2014

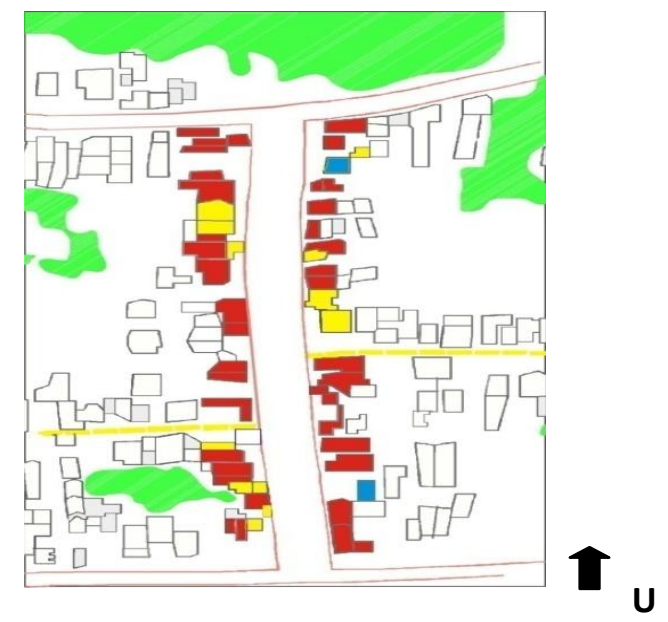

Gambar 3: Tata guna lahan Jl Kramat II Sumber: Peta Persil-Dokumen Penelitian, 2014

Ket gambar 3:

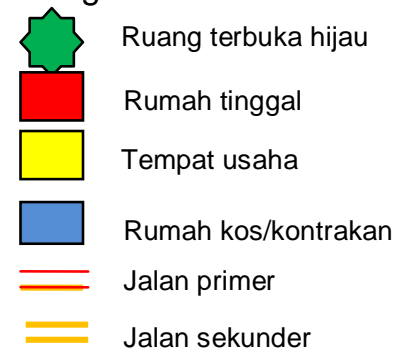

\subsection{Pola pemanfaatan ruang pada koridor jalan Kramat II}

Pemanfaatan ruang pada koridor jalan Kramat II dibagi menjadi pemanfaatan ruang pada aktivitas sehari-hari yang diobservasi dari hari Senin hingga hari Minggu dan pada saat pelaksanaan selamatan desa. Pemanfaatan ruang pada aktivitas sehari-hari terdapat pengelompokan aktivitas yang dilakukan oleh warga yang dapat dibedakan menjadi ruang ekonomi, sosial dan pemanfaatan ruang publik sebagai area parkir. Pemanfaatan area-area tersebut dilakukan berdasarkan setting dan fungsi ruang yang digunakan untuk mendukung aktivitas yang dilakukan oleh warga tersebut.

Pemanfaatan ruang dapat berlangsung secara permanen yang dilakukan secara rutin ataupun bersifat sementara. Batasan ruang yang terjadi dalam pemanfaatan ruang tersebut juga dapat dibedakan menjadi batasan fisik bangunan seperti toko ataupun batas jalan dan batasan yang bersifat massif yang hanya berdasarkan aktivitas yang terjadi. Pelaku pemanfaatan ruang dalam aktivitas seharihari ini dapat dibedakan menjadi wanita dewasa, laki-laki dewasa, remaja wanita, remaja laki-laki dan anak-anak.

Pelaksanaan selamatan desa yang dilaksanakan selama 3 hari lebih banyak terpusat pada spot 13 yang merupakan spot untuk panggung acara. Akan tetapi dampak dari adanya pelaksanaan kegiatan ini telah melebar hingga spot 4 . Dampak yang dihasilkan hanya berupa peningkatan intensitas pergerakan kendaraan bermotor yang melalui spot 1 hingga spot 3 .

Perbedaan pemanfaatan ruang pada koridor jalan Kramat II dibedakan berdasarkan spot yang dimanfaatkan oleh pelaku pemanfaatan tersebut. Spot yang paling jauh dari panggung acara lebih banyak digunakan untuk lahan parkir dan pemanfaatan oleh pedagang. Sedangkan spot yang paling dekat dengan panggung acara tentu saja digunakan untuk menyaksikan rangkaian acara selamatan desa.

Pembahasan berikutnya akan dipaparkan mengenai pola pemanfaatan koridor jalan Kramat II pada aktivitas sehari-hari dan pada saat pelaksanaan selamatan desa yang dianalisis dari segi lima elemen dasar pola pemanfaatan ruang dari Rapoport (1977).

\subsection{Pemanfaatan Jalan Kramat II pada aktivitas sehari-hari}

Hasil pengamatan dalam aktivitas dari hari Senin hingga hari Minggu ini menunjukkan bahwa pemanfaatan ruang pada jalan Kramat tersebut dibedakan menjadi ruang ekonomi, sosial dan perubahan pemanfaatan ruang pada jalan tersebut untuk lahan parkir motor ataupun parkir mobil. Pemanfaatan tersebut dapat berlangsung secara permanen ataupun secara temporal. Pelaku pemanfaat ruang terdiri dari laki-laki dewasa, remaja laki- 
laki, wanita dewasa, remaja wanita dan anak-anak.
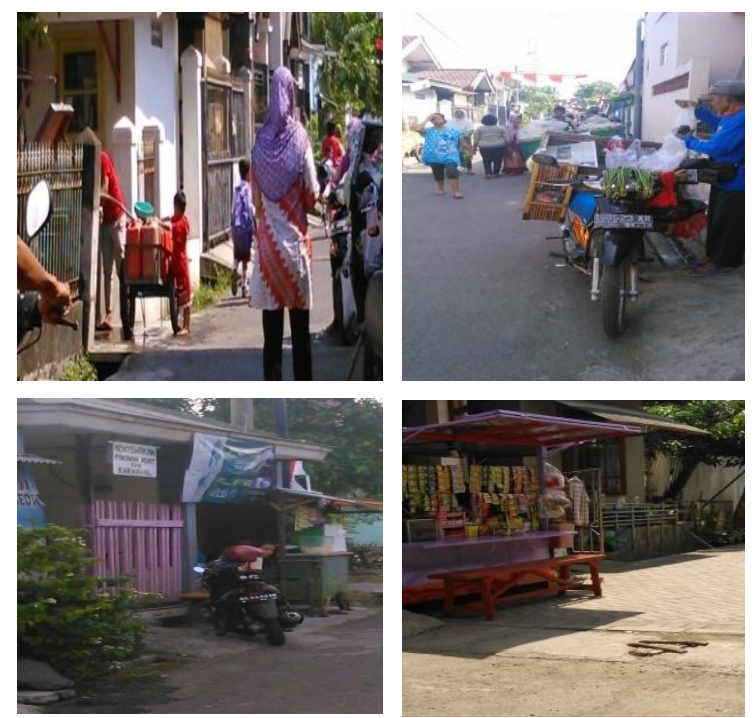

Gambar 4: Pemanfaatan spot untuk aktivitas ekonomi. Sumber: Observasi, 2014
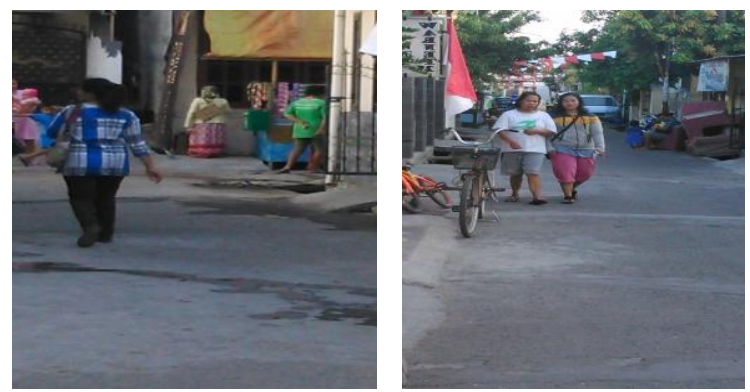

Gambar 5: Pemanfaatan spot untuk aktivitas sosial. Sumber: Observasi, 2014
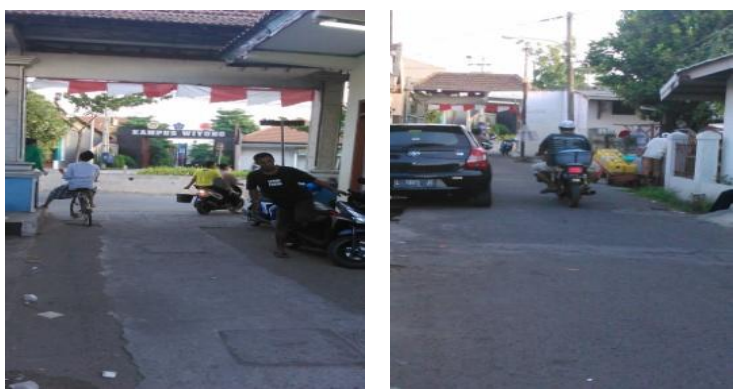

Gambar 6: Pemanfaatan spot untuk parkir Sumber: Observasi, 2014

Pola pemanfaatan jalan Kramat II untuk aktivitas sehari-hari, dapat dijabarkan dalam 5 aspek yang dikemukakan oleh Rapoport (1977) yaitu:

1. Ruang kegiatan manusia: kondisi permukiman yang padat di tengah perkotaan membuat ruang kegiatan manusia terutama untuk kegiatan ekonomi dan interaksi sosial lebih banyak memanfaatkan jalan utama kampung. Aktivitas ekonomi dan sosial tersebut berlangsung di koridor jalan Langkau Betang: Vol. 2, No.1 (ISSN 2355-2484) dan berlangsung secara temporal berdasarkan kepentingan dari warga yang memanfaatkannya.

2. Area inti: area inti sebagai area yang paling banyak dimanfaatkan oleh warga selain untuk jalur sirkulasi pada Jalan Kramat II ini terdapat pada spot 2 yang berada di depan pos RW hingga spot 5 . Pada spot 2 sampai spot 5 tidak hanya digunakan untuk penjual sayuran di pagi hari, akan tetapi juga digunakan untuk interaksi warga untuk mengurus administrasi kependudukan dan untuk bercengkrama di warung kopi. Sama halnya juga dengan spot 13 , yang sering digunakan untuk berkumpulnya ibu-ibu sambil mengasuh anak-anak mereka.

3. Teritori: teritori yang terlihat dalam pemanfaatan jalan Kramat II ini terdapat pada spot 2 hingga spot 5 yang merupakan teritori penjual sayuran dan pembeli di pagi hari dan spot 13 yang menjadi area anak-anak untuk bermain.

4. Area terkontrol: area terkontrol merupakan area yang digunakan oleh warga secara temporal untuk memnuhi kepentingannya sehingga area terkontrol di jalan ini terdapat pada spot 2,4,5,6 dan spot 14 yang digunakan untuk parkir motor dan mobil.

5. Ruang personal: ruang personal merupakan milik warga masing-masing yaitu rumah mereka.

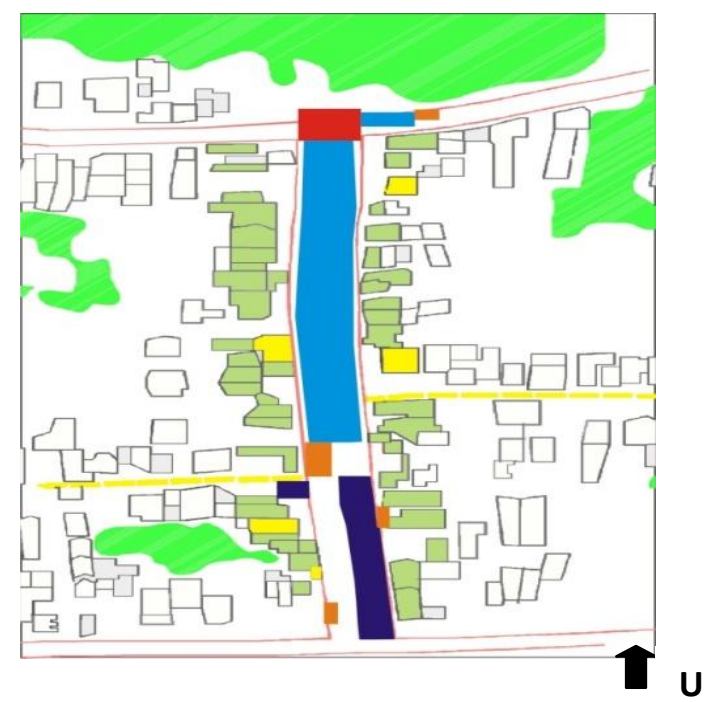

Gambar 7: Pemanfaatan spot pada aktivitas senarihari. Sumber: Peta Persil-Dokumen Penelitian, 2014 
Ket gambar 7:

$$
\begin{aligned}
& \text { Ruang kegiatan manusia } \\
& \text { Area inti: pusat kegiatan } \\
& \text { Teritori } \\
& \text { Area terkontrol: untuk parkir } \\
& \text { Ruang personal: rumah } \\
& \text { Warung/toko }
\end{aligned}
$$

Pola pemanfaatan ruang koridor jalan Kramat II pada aktivitas sehari-hari menunjukkan bahwa terdapat pemanfaatan ruang jalan untuk aktivitas warga dalam memenuhi kebutuhannya baik yang bersifat ekonomi, interaksi sosial maupun pemanfaatan ruang publik sebagai lahan parkir. Pola yang terbentuk pada aktivitas sehari-hari dari Senin hingga Minggu ini menunjukkan pemanfaatan yang hampir sama meskipun terdapat beberapa perbedaan aktivitas pemanfaatan pada akhir minggu.

Pola pemanfaatan ruang koridor jalan yang terjadi bersifat mengelompok dan menyebar di sepanjang jalan Kramat II ini pada spot-spot yang ada terutama jika spot tersebut berada dekat dengan warung, toko ataupun di wilayah yang rindang dan strategis untuk interaksi warga. Selain itu, dengan adanya pedagang atau sekelompok pedagang yang menggunakan badan jalan maka membuat area tersebut banyak dimanfaatkan oleh warga sehingga fungsi utama jalan sebagai ruang publik menjadi berubah peruntukkannya untuk sementara waktu.

\subsection{Pemanfaatan Jalan Kramat II pada pelaksanaan selamatan desa}

Selamatan desa dilaksanakan selama 3 hari yaitu pada hari Jum'at tanggal 30 Mei 2014 untuk pelaksanaan kenduren, hari Sabtu tanggal 31 Mei 2014 memiliki agenda acara yaitu selamatan panggung dan tenda, klenengan dan ludruk dan pada hari Minggu tanggal 01 Juni 2014 memiliki agenda acara yaitu pembacaan do'a dan pengajian umum. Pelaksanaan observasi dilakukan sama dengan pada aktivitas sehari-hari yaitu pada 14 spot dengan mengikuti setiap acara yang dilakukan.
Hasil pengamatan pada hari pertama menunjukkan bahwa pemanfaatan jalan Kramat II masih berlangsung seperti aktivitas sehari-hari. Ruang pada jalan ini yang dimanfaatkan dalam pelaksanaan kenduren mulai dari spot 7 yang digunakan untuk parkir motor, spot 8 yang digunakan untuk dapur umum dan spot 9 hingga spot 11 yang digunakan untuk pelaksanaan kenduren.
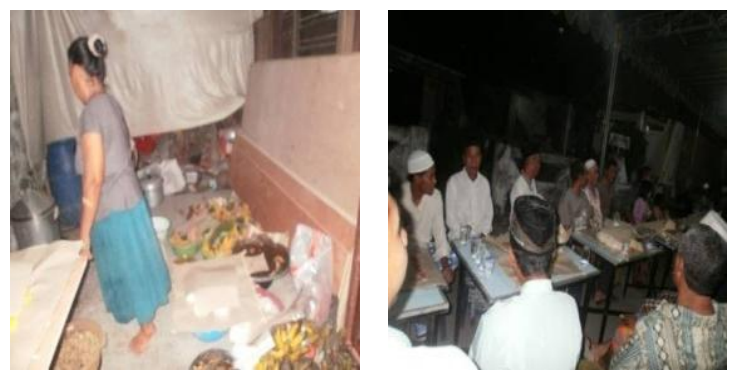

Gambar 8: Pemanfaatan spot pada H-1. Sumber: Observasi, 2014

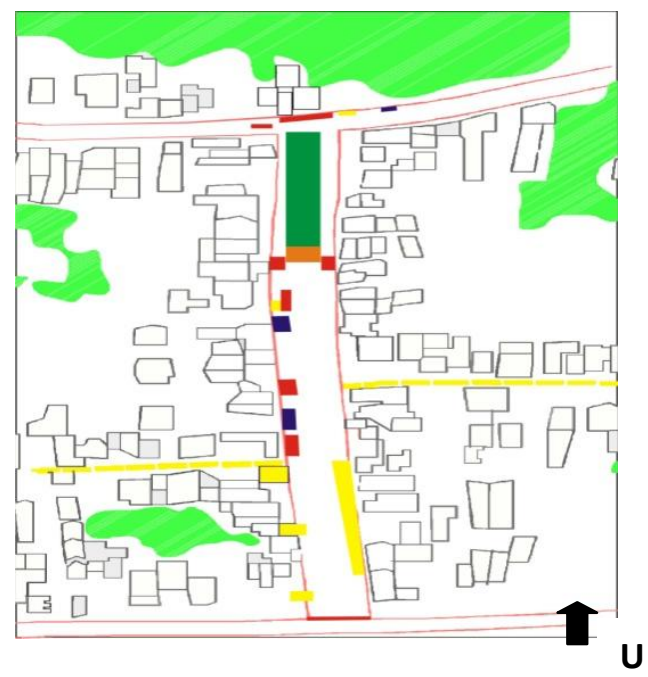

Gambar 9: Klasifikasi aktivitas pemanfaatan jalan pada H-1. Sumber: Peta PersilDokumen Penelitian, 2014

Ket gambar 9:

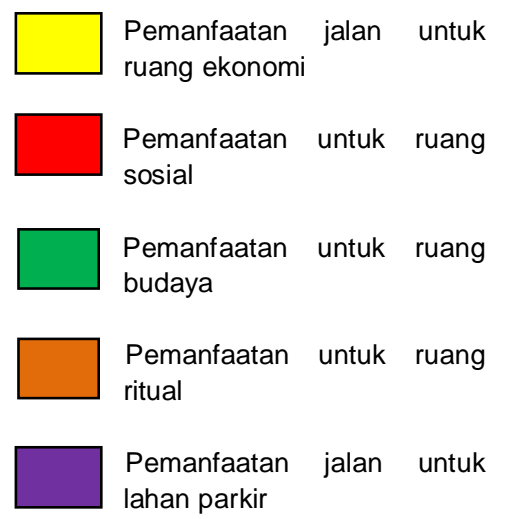

Hal. 48 
Hasil pengamatan pada hari kedua menunjukkan bahwa telah lebih banyak ruang pada jalan ini yang digunakan untuk pelaksanaan selamatan dan ludruk. Pada spot 1 sampai spot 3 masih dimanfaatkan oleh warga dalam aktivitas sehari-harinya. Penggunaan ruang pada jalan Kramat II ini untuk selamatan desa pada hari kedua ini terjadi pada spot 4 hingga spot 14 yang dibagi menjadi pemanfaatan untuk parkir, lapak pedagang, area untuk warga menyaksikan acara dan panggung acara.
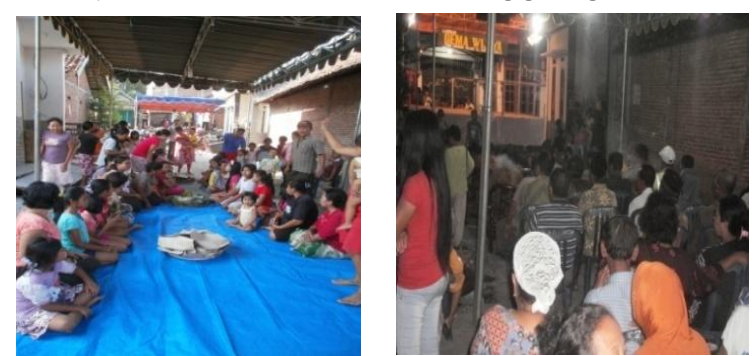

Gambar 10: Pemanfaatan spot pada hari $\mathrm{H}$. Sumber: Observasi, 2014

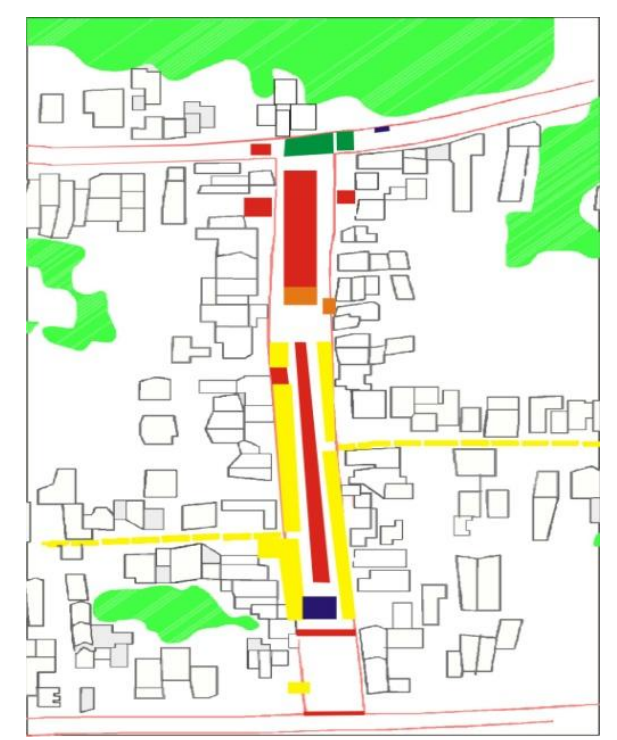

Gambar 11: Klasifikasi aktivitas pemanfaatan jalan pada hari H. Sumber: Sumber: Peta Persil-Dokumen Penelitian, 2014

Ket gambar 11:

\begin{tabular}{l}
\hline $\begin{array}{l}\text { Pemanfaatan jalan untuk } \\
\text { ruang ekonomi }\end{array}$ \\
$\begin{array}{l}\text { Pemanfaatan untuk ruang } \\
\text { sosial }\end{array}$ \\
$\begin{array}{l}\text { Pemanfaatan untuk ruang } \\
\text { budaya }\end{array}$ \\
$\begin{array}{l}\text { Pemanfaatan untuk ruang } \\
\text { ritual }\end{array}$ \\
$\begin{array}{l}\text { Pemanfaatan jalan untuk } \\
\text { lahan parkir }\end{array}$
\end{tabular}

Hasil pengamatan pada hari ketiga mengalami penurunan intensitas aktivitas dalam pemanfaatan ruang di jalan ini untuk pelaksanaan selamatan desa pada hari ketiga ini. Spot yang digunakan masih pada spot 4 hingga spot 13, akan tetapi terdapat penurunan aktivitas dan tidak seramai pada hari kedua.
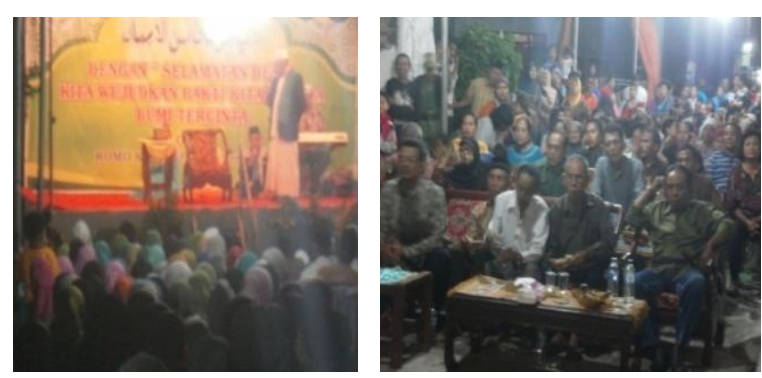

Gambar 12: Pemanfaatan spot untuk aktivitas pada hari $\mathrm{H}+1$. Sumber: Observasi, 2014

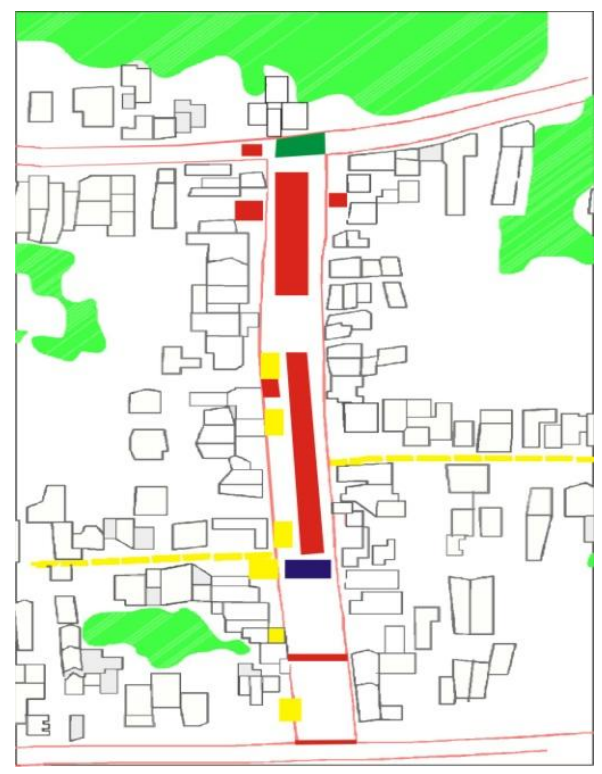

Gambar 13: Klasifikasi aktivitas pemanfaatan jalan Kramat II pada $\mathrm{H}+1$. Sumber: Peta PersilDokumen Penelitian, 2014

Ket gambar 13:

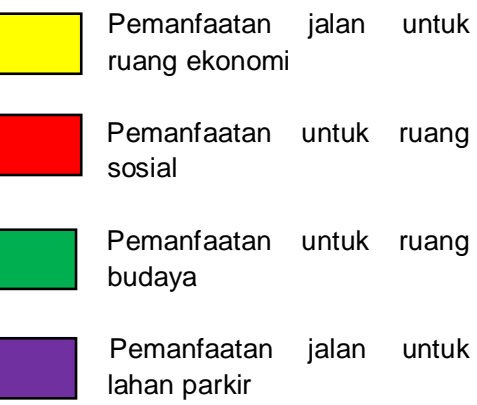


Pola pemanfaatan jalan untuk pelaksanaan selamatan desa ini juga dijabarkan dalam 5 aspek yaitu:

1. Ruang kegiatan manusia: ruang kegiatan manusia yang dimanfaatkan oleh warga pada selamatan desa lebih banyak terjadi pada spot 4 hingga spot 14. Spot 13 merupakan pusat pelaksanaan acara karena pada spot ini dimanfaatkan untuk panggung acara. Pelaksanaan ruang kegiatan di jalan tersebut dibedakan menjadi pemanfaatan untuk ruang ekonomi, ruang social, ruang budaya dan ruang ritual.

2. Area inti: area inti yang banyak digunakan oleh warga dalam pelaksanaan selamatan desa berada pada 13 yang menyebar ke sekitar panggung acara tersebut sebagai pendukung pelaksanaan acara selamatan desa.

3. Teritori: teritori yang terbentuk pada selamatan desa ini adalah spot 4 dampai spot 7 digunakan untuk lapak pedagang dan lahan parkir, spot 8 sampai spot 12 digunakan untuk warga menyaksikan acara yang berlangsung dan spot 13 sampai spot 14 digunakan untuk pengisi acara yaitu untuk pemain ludruk dan pengajian umum.

4. Area terkontrol: area terkontrol yang dimanfaatkan secara sementara oleh warga yaitu untuk lahan parkir dan untuk berdagang yang terdapat pada spot 4 hingga spot 7 ..

5. Ruang personal: ruang personal berada pada masing-masing rumah warga yang tidak dimanfaatkan langsung untuk mendukung jalannya pelaksanaan selamatan desa.

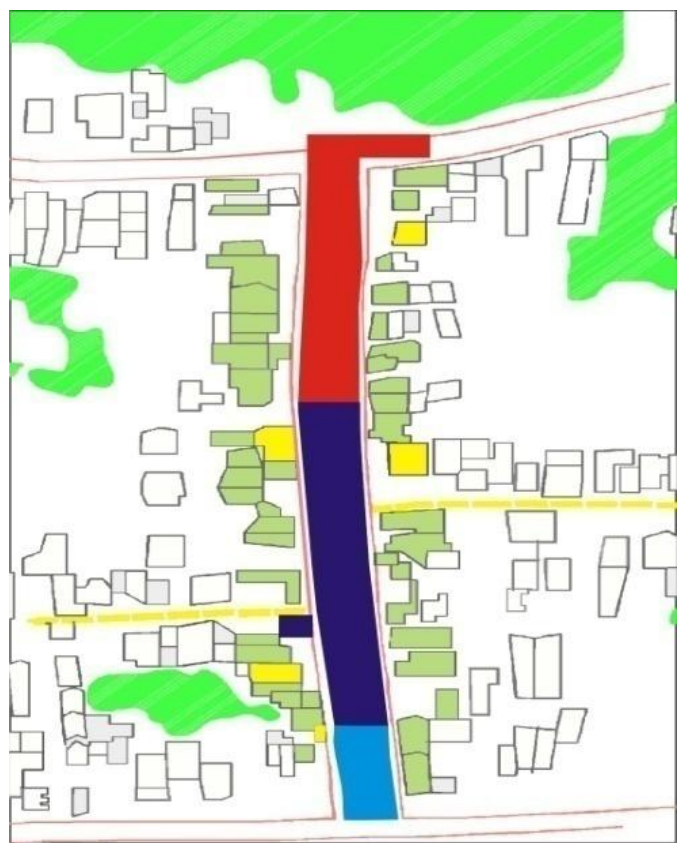

Gambar 14: Pola pemanfaatan ruang pada selamatan desa. Sumber: Peta Persil-Dokumen Penelitian, 2014

Ket gambar 14:

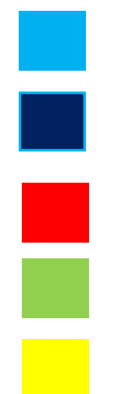
Ruang kegiatan manusia: sebagai jalur sirkulasi
Teritori dan area terkontrol: untuk pedagang dan parkir
Area inti: pusat kegiatan selamatan desa
Ruang personal: rumah masing- masing warga
Warung/toko

Pada ketiga hari pelaksanaan selamatan desa ini dapat terlihat adanya perbedaan pemanfaatan ruang. Pada hari pertama yaitu tanggal 30 Mei 2014 menunjukkan bahwa pemanfaatan koridor jalan belum banyak dimanfaatkan karena pada hari ini pelaksanaan acara masih melaksanakan acara kenduren saja. Pusat aktivitas warga di hari ini terletak pada spot 8 hingga spot 11 . Sedangkan pada spot - spot yang lain masih melaksanakan aktivitasnya sehari-hari dan belum banyak terpengaruh oleh adanya pelaksanaan kenduren yang dilaksanakan setelah shalat Isya'. Pelaksanaan kenduren tersebut dipersiapkan oleh ibu-ibu yang memasak dari pagi hari dan persiapan yang dilakukan oleh perangkat kampung dalam melaksanakan kenduren tersebut.

Pelaksanaan hari kedua selamatan desa pada tanggal 31 Mei 2014, menunjukkan adanya perbedaan aktivitas yang cukup signifikan. Hal tersebut 
dikarenakan pada spot 4 hingga spot 14 terjadi perbedaan besar dalam pemanfaatan ruang akibat adanya puncak acara selamatan desa tersebut. pelaksanaan ludruk sehingga mengundang banyaknya partisipasi warga. Perbedaan tersebut terlihat pada banyaknya lapak-lapak pedagang yang memanfaatkan koridor jalan yang ada, pemanfaatan jalan untuk lahan parkir, jalur sirkulasi warga menuju tempat pelaksanaan acara dan berkumpulnya warga di spot 6 hingga spot 11 untuk menyaksikan jalannya acara klenengan dan ludruk.

Pada hari ketiga pelaksanaan selamatan desa memiliki agenda acara yaitu pengajian umum. Di hari ketiga ini terdapat penurunan aktivitas dalam pemanfaatan koridor jalan yang terjadi sehingga kondisi jalan tidak seramai pada hari sebelumnya. Pemanfaatan koridor jalan untuk mendukung acara selamatan desa ini dimulai dari spot 5 hingga spot 13 yang memanfaatkan koridor jalan untuk jalur sirkulasi warga, pemanfaatan untuk lapak pedagang serta untuk lahan parkir motor. Berikut ini akan dipaparkan mengenai pola pemanfaatan ruang yang terjadi pada ketiga hari pelaksanaan selamatan desa tersebut.

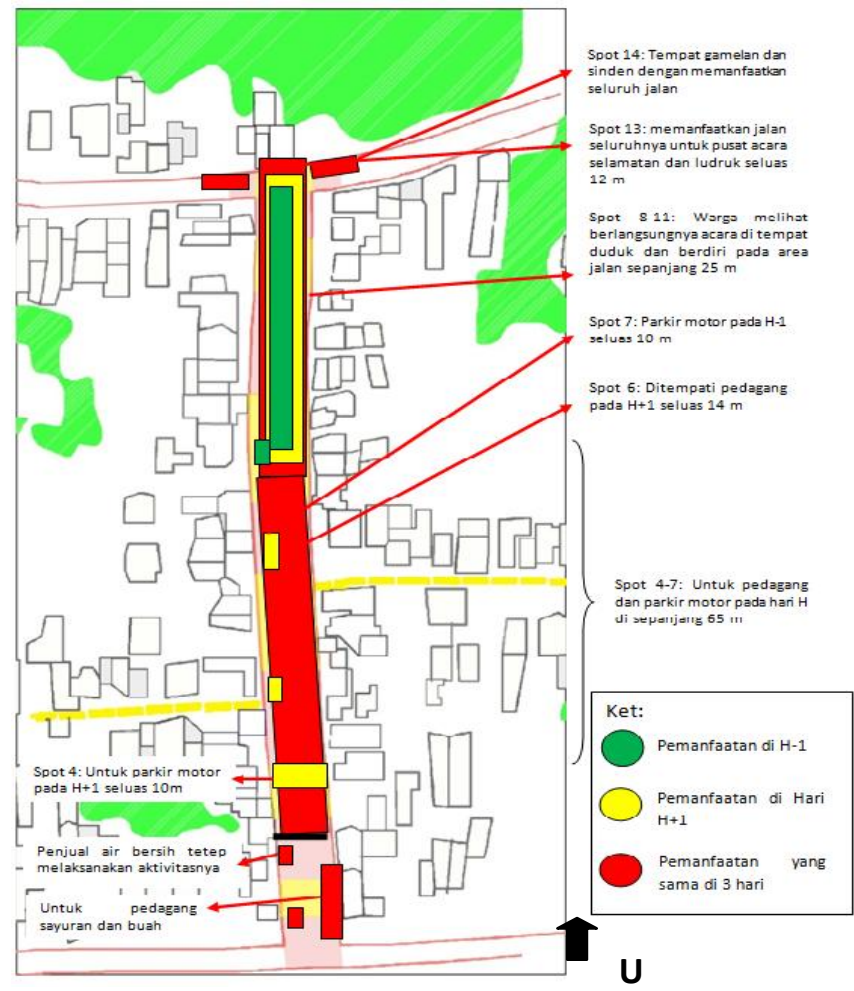

Gambar 15: Klasifikasi aktivitas pemanfaatan ruang pada pelaksanaan selamatan desa. Sumber: Peta Persil-Dokumen Penelitian, 2014
Pada tiga hari pelaksanaan selamatan desa tersebut, dapat terlihat bahwa pola pemanfaatan ruang di Jalan Kramat II berbentuk memanjang dan mengelompok. Masing - masing pengelompokan pada spot-spot yang ada di Jalan Kramat II dibedakan menjadi spot untuk panggung acara, tenda untuk warga menyaksikan jalannya acara, untuk pedagang dan parkir motor. Puncak aktivitas dari rangkaian kegiatan selamatan desa terjadi pada hari Sabtu tanggal 31 Mei 2014 dengan agenda acara berupa selamatan untuk tenda dan panggung, klenengan dan ludruk.

Pola pemanfaatan ruang dengan pemetaan perilaku place centered maps pada aktivitas sehari-hari membentuk pola yang mengelompok dan menyebar dengan pemusatan aktivitas masyarakat pada daerah yang rindang dan dekat dengan aktivitas ekonomi. Sedangkan pola pemanfaatan Jalan Kramat II pada saat pelaksanaan selamatan desa membentang di sepanjang jalan Kramat II sekitar $50 \mathrm{~m}$ dari gapura kampung hingga ujung Jalan Kramat II. Adanya perbedaan pola pemanfaatan ruang pada kedua aktivitas tersebut jika disatukan akan terlihat perubahan pemanfaatan ruang pada gambar berikut ini.

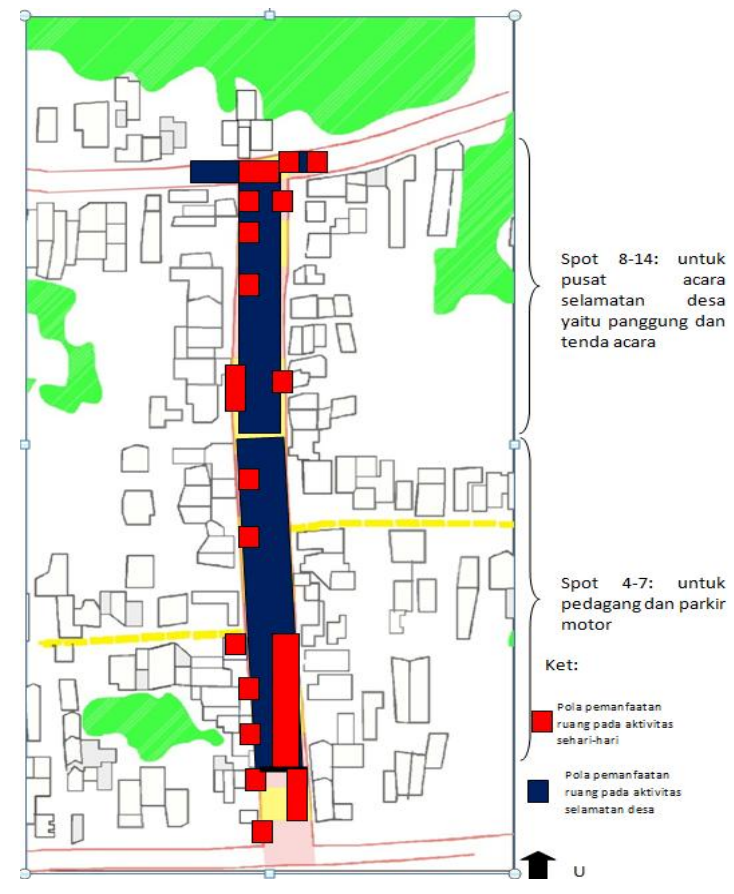

Gambar 16: Pola pemanfaatan ruang pada aktivitas sehari-hari dan saat selamatan desa. Sumber: Peta Persil-Dokumen Penelitian, 2014 
Dari dua pemanfaatan ruang pada aktivitas sehari-hari dan pada saat pelaksanaan selamatan desa tersebut berdasarkan metode place centered maps menunjukkan adanya 2 pola yang berbeda menurut aktivitas yang dilakukan yaitu sebagai berikut:

1. Pola pemanfaatan ruang koridor jalan Kramat II pada aktivitas sehari-hari menunjukkan bahwa terdapat pemanfaatan ruang jalan untuk aktivitas warga dalam memenuhi kebutuhannya baik yang bersifat ekonomi, interaksi sosial maupun pemanfaatan ruang publik sebagai lahan parkir. Pola yang terbentuk pada aktivitas sehari-hari dari Senin hingga Minggu ini menunjukkan pemanfaatan yang hampir sama meskipun terdapat beberapa perbedaan aktivitas pemanfaatan pada akhir minggu. Pola pemanfaatan ruang koridor jalan yang terjadi bersifat mengelompok dan menyebar di sepanjang jalan Kramat II ini pada spot-spot yang ada terutama jika spot tersebut berada dekat dengan warung, toko ataupun di wilayah yang rindang dan strategis untuk interaksi warga. Selain itu, dengan adanya pedagang atau sekelompok pedagang yang menggunakan badan jalan maka membuat area tersebut banyak dimanfaatkan oleh warga sehingga fungsi utama jalan sebagai ruang publik menjadi berubah peruntukkannya untuk sementara waktu.

2. Pola pemanfaatan ruang koridor jalan Kramat II pada aktivitas selamatan desa berbentuk memanjang di sepanjang jalan Kramat II dari spot 4 hingga spot 14 yang keseluruhan area tersebut dimanfaatkan oleh warga dalam pelaksanaan selamatan desa. Keseluruhan pemanfaatan tersebut digunakan untuk kegiatan ekonomi, social dan lahan parkir. Hanya pada spot 1 sampai spot 3 , aktivitas yang terjadi hanya berupa peningkatan aktivitas pergerakan warga dan kendaraan untuk menuju penyelenggaraan acara selamatan desa. Sedangkan hasil pemetaan perilaku dengan person centered maps, aktivitas masyarakat banyak terpusat pada spot 10 hingga spot 13 yang merupakan pusat penyelenggaraan acara untuk menyaksikan rangkaian acara selamatan desa serta membantu persiapan pelaksanaan acara selamatan desa tersebut. Perpaduan antara hasil pola pemanfaatan ruang melalui pemetaan perilaku place centered maps pada aktivitas seharihari dan pada saat aktivitas selamatan dessa dapat dijelaskan dalam gambar berikut ini.

\section{Kesimpulan}

Pola pemanfaatan ruang yang terbentuk pada aktivitas sehari-hari berbentuk mengelompok dan menyebar di sepanjang jalan Kramat II ini dan digunakan untuk kegiatan ekonomi, interaksi sosial antar warga dan untuk pemanfaatan lahan parkir. Pemanfaatan spot paling besar terjadi pada spot yang terletak di dekat warung atau toko atau pada spot yang dekat dengan daerah yang rindang. Sedangkan pola pemanfaatan yang terjadi pada aktivitas selamatan desa, berbentuk memanjang di sepanjang jalan Kramat II dan daerah di sekitarnya. Pemanfaatan pada ke-14 spot tersebut digunakan untuk mendukung kelancaran pelaksanaan selamatan desa. Akan tetapi pada spot 1-3 tidak banyak digunakan untuk mendukung pelaksanaan acara, pada spot tersebut hanya terjadi peningkatan intensitas pergerakan kendaraan bermotor. Spot 4 hingga spot 14 yang paling banyak dimanfaatkan untuk pelaksanaan selamatan desa mulai dari aktivitas ekonomi, interaksi sosial, lahan parkir, area warga untuk menyaksikan acara dan untuk panggung acara.

\section{Daftar Pustaka}

Haryadi \& Bobby Setiawan. 1995. Arsitektur Lingkungan dan Perilaku: Teori, Metodologi dan Aplikasi. Yogyakarta: Proyek Pengembangan Pusat Studi Lingkungan: Departemen Pendidikan dan Kebudayaan

Lang, John. 1987. Creating Architectural Theory. Van Nostrand Reinhold Co. New York.

Laurens, Joyce.2004. Arsitektur dan Perilaku Manusia. PT. Grasindo. Jakarta 
Rapoport, Amos. 1977. Human Aspects of Urban Form: Towards A ManEnviromental Approach to Urban Form And Design. Pergamon Press, New York.

Wahid, Julaihi \& Bhakti Alamsyah. 2013. Teori Arsitektur: Suatu Kajian Perbedaan Pemahaman Teori Barat dan Timur. Graha IImu. Yogyakarta

Zeisel, John. 1981. Inquiry by Design: Environment/Behavior/Neuroscience in Architecture, Interiors, Landscape and Planning. Wadsworth Inc, Belmont. California 